3. Vashchenko, O. M. \& Svyrydenko, S. O. (2008). Ozdorovcha robota na HPD [Health work during extended day groups]. Methodical guide. Primary education. pp.311. [in Ukrainian].

4. Vashchenko, O. M. (2017). Pedahohichni umovy orhanizatsiia zdoroviazberezhuvalnoho seredovyshcha pochatkovoi shkoly [Pedagogical conditions, organization of the health-preserving environment of primary school]. Health education. Chernihiv, Vol.1. pp.119-125. [in Ukrainian].

5. Vashchenko, O. M. \& Kikosh, O. V. (2014). Pidhotovka maibutnoho vchytelia do zdoroviazberezhuvalnoi diialnosti u pochatkovii shkoli yak naukova problema [Preparing future teachers for health care activities in primary school as a scientific problem]. Pearls of scientific research: coll. Science. articles. Khmelnytskyi, book.2. pp. 18-24. [in Ukrainian].

6. Dolynskyi, B.T.(2010). Metodolohiiazdoroviazberihaiuchoi diialnosti maibutnoho vchytelia pochatkovoi shkoly [Methodology of health-preserving activity of the future primary school teacher]. Odessa, 266 p. [in Ukrainian].
7. Kondratiuk, S.M. (2003). Intehratyvnyi pidkhid do vykhovannia u molodshykh shkoliariv zdorovoho sposobu zhyttia [An integrative approach to educating younger students in a healthy lifestyle]. Extended abstract of candidate's thesis. Kyiv, $20 \mathrm{p}$. [in Ukrainian].

8. Naumenko, Yu.V. (2005). Zdoroviazberezhuvalna diialnist shkoly [School health activities]. Pedagogy. pp.3744. [in Ukrainian].

9. Natsionalna doktryna rozvytku osvity Ukrainy u XXI stolitti (2001). [National doctrine of education development of Ukraine in the XXI century]. School world.Kyiv, 24 p. [in Ukrainian].

10. Smirnov, N.K. (2002). Zdorovesberegayushchie obrazovatelnye tekhnologii v sovremennoy shkole [Healthsaving educational technologies in the modern school]. Moscov, 121p.[in Russian].

11. Cokpatova, N.V. (2005). Covpemennye tekhnologii cokhpaneniya i ukpepleniya zdopovya detey [Modern technologies of preservation and strengthening of health of children]. Study aid. Moscov, 224 p. [in Russian].

УДК 7717 [378.147:51]:[37.091.212:62]

DOI:

Альона Коломієць, кандидат педагогічних наук, доцент, доцент кафедри вищої математики Вінницького національного технічного університету

\title{
ПОБУДОВА ПЕДАГОГІЧНОЇ СИСТЕМИ ФУНДАМЕНТАЛІЗАЦІЇ МАТЕМАТИЧНОЇ ПІДГОТОВКИ МАЙБУТНІХ БАКАЛАВРІВ ТЕХНІЧНИХ СПЕЦАЛЛЬОСТЕЙ
}

У статті розглянуто основні підходи до визначення понять “фундаменталізачія”, “система”, “педагогічна система”, проведено аналіз досліджень науковців з обраної теми; проаналізовано підходи до тлумачення дефініцій “фундаменталізація”, “система”, названо основні функціональні компоненти ПС фундаменталізації математичної підготовки майбутніх бакалаврів технічних спеціальностей, наведено приклад фундаменталізації математичних понять для студентів технічних спеціальностей. Проведено опис елементів системи фундаменталізації математичної підготовки майбутніх бакалаврів технічних спеціальностей. До ї̈ складових віднесено гностичну, організаторську, конструктивну, комунікативну, проектувальний складові.

Ключові слова: майбутні бакалаври; технічні спеціальності; математична підготовка; педагогічна система; системний підхід; фундаменталізація; фундаменталізачія математичної підготовки.

Рис. 1. Табл. 2. Літ. 13.

\author{
Alona Kolomiiets, Ph.D.(Pedagogy), Associate Professor \\ Associate Professor of the Higher Mathematics Department \\ Vinnytsya National Technical University
}

\section{BUILDING A PEDAGOGICALSYSTEM FUNDAMENTALIZATION OF MATHEMATICAL PREPARATION OF FUTURE BACHELOR OF TECHNICAL SPECIALTIES}

The main approaches to the definition of the concepts of fundamentalization system, pedagogical system are considered in the work, the analysis of researches of scientists on the chosen theme is carried out. The precondition for the problem of fundamentalization of mathematical training of students of technical specialties was the rapid growth of mathematical knowledge and the impossibility of their reflection in the structure of the educational process of students of technical specialties. The search for ways to solve this problem led to the idea of fundamentalization, which involves the selection and study of fundamental sections, topics, concepts of the discipline in accordance with the technical specialty in which students study.

One of the preconditions that led to the emergence of a systematic approach was the attempt of scientists to 


\section{ПОБУДОВАПЕДАГОГІЧНОЇ СИСТЕМИ ФУНДАМЕНТАЛІЗАЦЇ МАТЕМАТИЧНОЇПІДОТОВКИ МАЙБУТНІХБАКАЛАВРІВ ТЕХНІЧНИХСПЕЦІАЛЬНОСТЕЙ}

build models of pedagogical work of the teacher, which would affect the quality of the educational process, and with these models could predict the results of educational activities.

The aim of the work is to analyze some approaches to the interpretation of the definitions of "fundamentalization", "system", to give the main functional components of the PS fundamentalization of mathematical training of future bachelors of technical specialties.

According to the purpose of the work, the following methods were used to study this problem: analysis of literature sources, scientific literature, synthesis of the obtained information.

A comparative analysis of approaches to the definition of the studied concepts, analyzed the structural and functional components of the pedagogical system developed by N. Kuzmina, which includes structural and functional components.

Under the fundamentalization of mathematical training of future bachelors of technical specialties we understand the pedagogical system, the introduction of which into the educational process is a significant improvement in the quality and level of mathematical training of students through appropriate changes in mathematical disciplines, allocation of invariant knowledge of relevant fundamental topics.

The paper lists the functional features of the fundamentalization of mathematical training of future engineers: the selection of fundamental topics, sections; structuring the content of mathematical training in accordance with the requirements of special disciplines.

The description of elements of pedagogical system of fundamentalization of mathematical preparation of future bachelors of technical specialties is carried out. Its components include gnostic, organizational, constructive, communicative, design components.

Fundamentalization of mathematical concepts takes place in the context of the whole system of fundamentalization of mathematical training of future bachelors of technical specialties. Under the fundamentalization of the concept we understand the selection of this concept as basic and invariant and the construction around this concept of a system of actions in order to maximize its assimilation by students. An example of step-by-step fundamentalization of the mathematical concept of "function boundary" is given.

Keywords: future bachelors; technical specialties; mathematical training; pedagogical system; system approach; fundamentalization; fundamentalization of mathematical training.

П остановка проблеми. Феномен фундаменталізації на сучасному етапі розвитку технічної освіти є невід'ємною ії частиною. Обсяг наукової інформації 3 кожним роком зростає експоненціально, а відображення іiї у освітньому процесі неможливе тією мірою, у якій вона з'являється. Корелювання цих двох процесів багато дослідників вбачають у фундаменталізащії освітнього процесу.

Фундаменталізація освітнього процесу, i зокрема фундаменталізація математичної підготовки майбутніх бакалаврів технічних спеціальностей у контексті їхньої професійної підготовки, займає провідну позицію у наукових сучасних дослідженнях. Явище фундаменталізації більшою чи меншою мірою охоплює всі структурні елементи освітнього процесу. Проблемі фундаменталізації навчання у вищій школі присвячено чимало уваги. Ї̈̈ досліджували низка українських і зарубіжних вчених, зокрема, С. Гончаренко, Г. Дутка, С. Казанцев, Е. Лузік, Н. Морзе, С. Семеріков та інші. Проблемі фундаменталізації професійної сучасної вищої технічної та технологічної освіти присвячено наукові студії С. Архангельського, С. Баляєвої, А. Вербицького, С. Гончаренка Г. Дугки, С. Казанцева, В. Кондратьєва, В. Сергіївського, А. Субетто, А. Суханова, Н. Тализіної, О. Філатова, М. Читаліна та інших вчених.

Поняття фундаменталізація освіти у своїх роботах дослідники трактують по-різному. До основних означень належать такі: дидактичний принцип (О. Субетто, Г. Дутка); процес якісної зміни вищої освіти (М. Ковтонюк); система умов проєктування фундаментального освітнього простору(А.Хугорський). Дефініція “фундаменталізація” означена науковцямипереважно логіко-інтуїтивним чином, і одностайності серед науковців у цьому питанні немає. Водночас, ведучи мову про фундаменталізацію певної категорії, вони мають на увазі таку систему, у якій відбувається виділення основних базових елементів цієї категорії, на яких, як на фундаменті будуть, вибудовуватися інші елементи категорії, тобто фундаменталізація чого-небудь (освіти, освітнього процесу тощо), передбачає виокремлення фундаментальних основ, їх систематизацію і структурування певним чином. Автори $[4,38]$ підкреслюють, що “фундаменталізація” передбачає застосування індивідуального підходу до студента, формування його світогляду, стимулювання академічної “мобільності”, і зазначають, що “фундаменталізація” вищої технічної освіти передбачає базові знання, сформовані в єдину “картину світу” за допомогою міжпредметної інтеграції”. Зазначене безпосередньо вказує на ідею системності та присутність системи у процесі фундаменталізації освітнього процесу.

Уважаємо, що фунадаменталізація математичної 


\section{ПОБУДОВА ПЕДАГОГІЧНОЇ СИСТЕМИ ФУНДАМЕНТАЛІЗАЦЇ МАТЕМАТИЧНОЇ ПІГОТОВКИ МАЙБУТНІХБАКАЛАВРІВ ТЕХНІЧНИХСПЕЦАЛЬНОСТЕЙ}

підготовки майбутніх інженерів - бакалаврів технічних спеціальностей - передбачає таку педагогічну систему, впровадження якої у загальну підготовку майбутнього фахівця сприятиме уніфікації, систематизації математичних знань, виділенню ядра фундаментальних знань і вмінь, систематизацію та класифікацію основних математичних понять, інтеграцію теоретичної і практичної частини математичних та спеціальних дисциплін. Результатом фундаменталізації професійної підготовки є набуття фахівцями системних, універсальних знань, які є основою для професійної мобільності майбутнього інженера.

Не маючи загальновизначеного визначення, у наукових працях поняттю фундаменталізації притаманні основні ознаки системи, відповідно його дослідження потрібно проводити саме у контексті проблемного поля “системи”.

Вивченню проблемного поля феномену “система” присвячено увагу у роботах М. Воропаєва, В. Ковальчук, Н. Кузьміної та ін. 3 другої половини XX ст. педагоги-дослідники розпочали активний пошук методів та засобів удосконалення i підвищення якості освітнього процесу, за рахунок нових конструйованих педагогічних прийомів, які включали б можливість прогнозування результатів навчальної роботи педагога, елементи моделювання процесу якісної зміни особистості (ii інтелектуального, психологічного росту) у створених педагогічних умовах. Вивчення та впровадження педагогічних систем в освітній процес відбувається у контексті системного підходу.

Мета дослідження - проаналізувати деякі підходи до тлумачення дефініцій “фундаменталізація”, “система", навести основні функціональні компоненти ПС фундаменталізації математичної підготовки майбутніх бакалаврів технічних спеціальностей, навести приклад фундаменталізації математичних понять для студентів технічних спеціальностей.

Методологія. У процесі написання розвідки було використано теоретичні методи дослідження. Аналіз літературних джерел, наукової літератури, аналіз і синтез досліджень науковців проблемного поля, що стосується побудови педагогічної системи.

Результати дослідження. На сучасному етапі розвитку педагогічної науки системний підхід розглядається як напрям у методології науки, завданням якого є розробка методів дослідження й конструювання складних за організацією об'єктів як систем, розкриття їх цілісності, виділення у них різноманітних типів зв'язків та зведення їх у єдину теоретичну картину.
Центром понятійного апарату системного підходу є дефініція - “система”. Певна група дослідників за основу своїх досліджень брали ідею про те, що освітній процес - це цілісна система, множина взаємопов'язаних елементів, які виділені за певними критеріями, мають спільну мету функціонування, наслідком якої є взаємодія цієї множини елементів як єдиного цілісного явища (процесу). До цієї групи належать Ю. Бабанський, М. Данілов, В. Ільїн, В. Коротов, В. Раєвський, Б. Ліхачов $[10,157]$.

Д. Чернілевський у своїх дослідженнях підкреслює, що система - це цілісна множина взаємопов'язаних елементів, компонентів, підсистем. При чому система має функції, цілі, структуру; і характеризується такими ознаками: цілісність, структурність, взаємозв'язок із зовнішнім середовищем, ієрархічність, цілеспрямованість, самоорганізація [13, 171-172].

Розглянемо поняття педагогічної системи через призму іiі змістового та функціонального компонентів. У найперших спробах науковців дати цілісне визначення цій дефініції знаходимо: “система" (з гр. - поєднання, влаштування, об'єднання) - сукупність якісно визначених елементів, між якими існує закономірний зв'язок або взаємодія [12, 427].

Представник сучасних науковців цієї проблеми Т. Жижко підкреслює що “система - це сукупність діалектично пов'язаних між собою елементів, які $\epsilon$ основою забезпечення цілісності явищ і процесів як у природі, так і у суспільстві” [3].

Тому під поняттям системи будемо розуміти сукупність пов'язаних елементів, яка покладена в основу иілісності та єдності процесів $i$ явищ, щзо відбуваються у навколишньому середовищі, і яка є ключем до розуміння їх сутності.

У своїх дослідженнях Н. Кузьміна досить грунтовно розробила поняття системи та ввела поняття "педагогічна система" [9], до основних компонентів якої відносить:

- цільові аспекти,

- навчальну інформацію,

- суб'єктів навчальної діяльності,

- засоби педагогічної комунікації (форми, методи, засоби).

Перераховані компоненти відрізняють педагогічну систему від непедагогічної.

"Педагогічну систему можна визначити як сукупність взаємопов’язаних структурних i функціональних компонентів, які підпорядковуються цілям виховання, освіти і навчання підростаючого покоління і дорослих людей” [9].

У роботах ученої наведено функціональні та 
ПОБУДОВАПЕДАГОГІЧНОЇ СИСТЕМИ ФУНДАМЕНТАЛЗАЦЇ̈ МАТЕМАТИЧНОЇ ПІДГОТОВКИ МАЙБУТНІХ БАКАЛАВРІВ ТЕХНІЧНИХ СПЕЦАЛЬНОСТЕЙ

\begin{tabular}{|c|c|}
\hline \multicolumn{2}{|c|}{ Структурно-функціональні компоненти педагогічної системи (ПС) за Н.Кузьміною } \\
\hline Функціональні компоненти ПС & Структурні компоненти ПС \\
\hline Проектувальний & Мета \\
\hline Гностичний & Педагог \\
\hline Організаторський & Студенти/учні \\
\hline Комунікативний & Засоби педагогічної взаємодії \\
\hline Конструктивний & Навчальна інформація \\
\hline
\end{tabular}

структурні компоненти педагогічної системи (Таблиця 1).

Під педагогічною системою розуміємо комплекс взаємопов'язаних структурних елементів, які у своєму поєднанні дають змогу створити умови для досягнення педагогічних цілей освітнього процесу. У дослідженні М. Ковтонюк підкреслено, що педагогічні системи мають динамічний характер і тенденцію до змін та вдосконалень [6,86].

Як було обгрунтовано у нашій роботі [8], фундаменталізація освітнього процесу має ознаки системи та виконує системотвірну функцію.

Фундаменталізація математичної підготовки майбутніх бакалаврів технічних спеціальностей передбачає:

- виділення фундаментальних тем, розділів дисципліни - елементів знань (виділення фундаментального теоретичного ядра у змісті) 3 метою надання їм базового першочергового значення і побудові на основі нових знань,

- структурування змісту математичної підготовки згідно з вимогами спецдисциплін (зміна в навчальних програмах дисципліни: включення деяких додаткових тем до навчальних програм дисципліни “Вища математика”),

- включення до процесу навчання допоміжних пакетів СКМ, з метою розширення можливостей прикладного застосування математичного апарату до розв'язання прикладних задач професійного спрямування [11]. Враховуючи окреслені функціональні ознаки фундаменталізації математичної підготовки майбутніх інженерів, цю дефініцію ми визначимо так.

Фунадаменталізація математичної підготовки майбутніх інженерів - бакалаврів технічних спеціальностей - передбачає таку педагогічну систему підвищення якості і рівня математичної підготовки, впровадження якої у загальну підготовку майбутнього інженера сприятиме уніфікації, систематизації математичних знань, виділенню ядра фундаментальних знань та вмінь, систематизації та класифікації основних математичних понять, інтеграції теоретичної і практичної частини математичних та спеціальних дисциплін, що забезпечує потенціал ії професійної адаптивності.

Водночас процес фундаменталізації математичної підготовки націлений на посилення фундаментальних складових дисциплін природничого циклу з метою підготовки конкурентоздатного фахівця [5].

На думку дослідниці М. Ковтонюк, фундаменталізацію професійної підготовки майбутнього вчителя математики слід розглядати у контексті педагогічної системи “системи освіти”, яка містить підсистеми “університет”, “факультет”, “кафедра” [6].

Математична підготовка майбутніх бакалаврів технічних спеціальностей є педагогічною системою і підсистемою систем "професійна підготовка інженера”, “загальнопрофесійна підготовка інженера”, “соціальний розвиток інженера".

Візьмемо за основу сформовану Н. Кузьміною структурно-функціональну модель педагогічної системи. На іiі основі побудуємо модель педагогічної системи фундаменталізації математичної підготовки фахівців технічних спеціальностей.

Ми вважаємо, що функціональні компоненти педагогічної системи фундаменталізації математичної підготовки майбутніх фахівців технічних спеціальностей для викладача i студента не повинні бути роздільні, оскільки ці дві групи завжди доповнюють одна одну та функціонують разом. Цілісна система фундаменталізації математичної підготовки майбутніх бакалаврів технічних спеціальностей можлива лише за тісної співпраці викладача та студентів. Функціональні компоненти педагогічної системи фундаменталізації математичної підготовки представлені у таблиці (Таблиця 2.)

Як зазначає В. Беспалько, фундаментальна підготовка майбутнього інженера спрямована на посилення взаємозв'язків теоретичної й практичної підготовки молодого фахівця до професійної діяльності [2]. Така підготовка впливає на формування цілісної наукової картини 
Таблиця 2.

Функціональні компоненти ПС фундаменталізації математичної підготовки майбутніх бакалаврів технічних спеціальностей (На основі компонент ПС за Н Кузьміною)

\begin{tabular}{|c|c|c|}
\hline & Викладач & Студент \\
\hline 窐 & $\begin{array}{l}\text { Уміння дослідити початковий рівень } \\
\text { математичних знань та вмінь майбутніх } \\
\text { бакалаврів технічних спеціальностей } \\
\text { (нульова контрольна робота, тестові } \\
\text { завдання), знання загальної цілісної } \\
\text { структури навчального процесу, та вміння до } \\
\text { його корекції, що приводить до якісної } \\
\text { математичної підготовки студентів. Уміння } \\
\text { викладача підібрати такі задачі } \\
\text { математичного та прикладного характеру, } \\
\text { при розв’язанні яких студент набуде } \\
\text { математичних вмінь і знань, у обсязі, } \\
\text { необхідному для інженерної діяльності. } \\
\text { Вміння прогнозувати результати } \\
\text { педагогічного процесу, застосованої } \\
\text { методичної системи }\end{array}$ & $\begin{array}{l}\text { Уміння виділяти головне із усього обсягу } \\
\text { інформації, розуміти взаємозв'язки між на } \\
\text { перший погляд різним математичним } \\
\text { матеріалом. Уміння схематично зображати } \\
\text { математичну інформацію. } \\
\text { Уміння проводити аналіз, синтез математичної } \\
\text { інформації, робити узагальнення та } \\
\text { систематизацію математичної інформації. } \\
\text { Уміння підбирати, конструювати розв’язки до } \\
\text { різного типу задач дисципліни вища } \\
\text { математика. }\end{array}$ \\
\hline 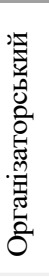 & $\begin{array}{l}\text { Організувати свій час та діяльність, що } \\
\text { пов’язана із викладацькою роботою, щоб } \\
\text { сплановувати та структурувати власну } \\
\text { роботу та роботу студентів. Організовувати } \\
\text { колективну та самостійну роботу студентів, } 3 \\
\text { метою покращення якості математичних } \\
\text { знань. Організовувати та сприяти навчально- } \\
\text { дослідницькій діяльності студентів. }\end{array}$ & $\begin{array}{l}\text { Уміння до самоорганізації, вміння вчасно } \\
\text { закінчувати розпочату діяльність, у тому числі } \\
\text { проекти, виступи на гуртках, конференціях, } \\
\text { вміння планувати свій час, в тому числі під час } \\
\text { проведення рубіжних та семестрових } \\
\text { контрольно-оцінювальних тестів. }\end{array}$ \\
\hline 空 & $\begin{array}{l}\text { Конструювати математичну навчальну } \\
\text { інформацію з метою найкращої } \\
\text { раціоналізації та поєднання видів діяльності } \\
\text { студентів, що обумовлює якісну } \\
\text { математичну підготовку. }\end{array}$ & $\begin{array}{l}\text { Уміння конструювати розв’язки задач та } \\
\text { будувати алгоритми покрокового розв’язання, } \\
\text { вміння класифікувати типи задач і підбирати } \\
\text { до них алгоритми розв’язання, будувати схеми, } \\
\text { що відповідають алгоритму розв’язку задачі } \\
\text { або допомагають при розв'язанні задачі. }\end{array}$ \\
\hline 焉 & $\begin{array}{l}\text { Передавати математичну інформацію у } \\
\text { вербальній та письмовій формі, доступній } \\
\text { для студентів, наводити життєві та } \\
\text { професійні приклади застосування } \\
\text { математичних знань. Будувати лекційний } \\
\text { курс з акцентом на формування } \\
\text { пізнавального інтересу та зацікавлення } \\
\text { навчальним матеріалом у студентів. }\end{array}$ & $\begin{array}{l}\text { Уміння чітко формулювати запитання } \\
\text { стосовно незрозумілих частин математичної } \\
\text { інформації та способів розв’язання } \\
\text { математичних задач, виділяти із загальної } \\
\text { інформації незрозумілі частини та чітко їх } \\
\text { словесно описувати із застосуванням } \\
\text { математичної мови. }\end{array}$ \\
\hline 焉 & $\begin{array}{l}\text { Проєктувати навчальну діяльність студентів } \\
\text { з урахуванням 1) індивідуальних } \\
\text { особливостей студентів групи, 2) сучасних } \\
\text { вимог до кваліфікаційного рівня інженера } \\
\text { Формулювати завдання для студентів у } \\
\text { контексті формування пізнавального } \\
\text { інтересу та розуміння прикладного значення } \\
\text { начального математичного знання, а також } \\
\text { розвитку дослідницьких вмінь студентів. } \\
\text { Будувати процес вивчення математичних } \\
\text { дисциплін відповідно до потреб спец кафедр } \\
\text { та майбутньої професійної діяльності } \\
\text { студентів. }\end{array}$ & $\begin{array}{l}\text { Уміння окреслювати цілі розв’язання } \\
\text { конкретних задач, розуміти прикладне } \\
\text { застосування математичного апарату. Вміння } \\
\text { виділяти “математичне ядро” та чітко його } \\
\text { занотовувати, Вміння будувати логічні } \\
\text { математичні повідомлення з висновками } \\
\text { (доповіді на конференціях, гуртках). Уміння } \\
\text { розробляти та виконувати проєкти, планувати } \\
\text { цілі закінчення проектів, розраховувати час на } \\
\text { їх виконання. }\end{array}$ \\
\hline
\end{tabular}

навколишнього світу, індивідуально-професійний розвиток студента, формування його професійної компетентності, що в сукупності забезпечує високу якість освіти.

У процесі фундаменталізації математичної підготовки майбутніх бакалаврів технічних спеціальностей відбувається також фундаменталізація математичних понять, зокрема у системі “Дисципліна, розділ, тема, поняття" (Рис. 1)

Наведена система є підсистемою усієї системи фундаменталізації математичної підготовки майбутніх бакалаврів технічних спеціальностей. 


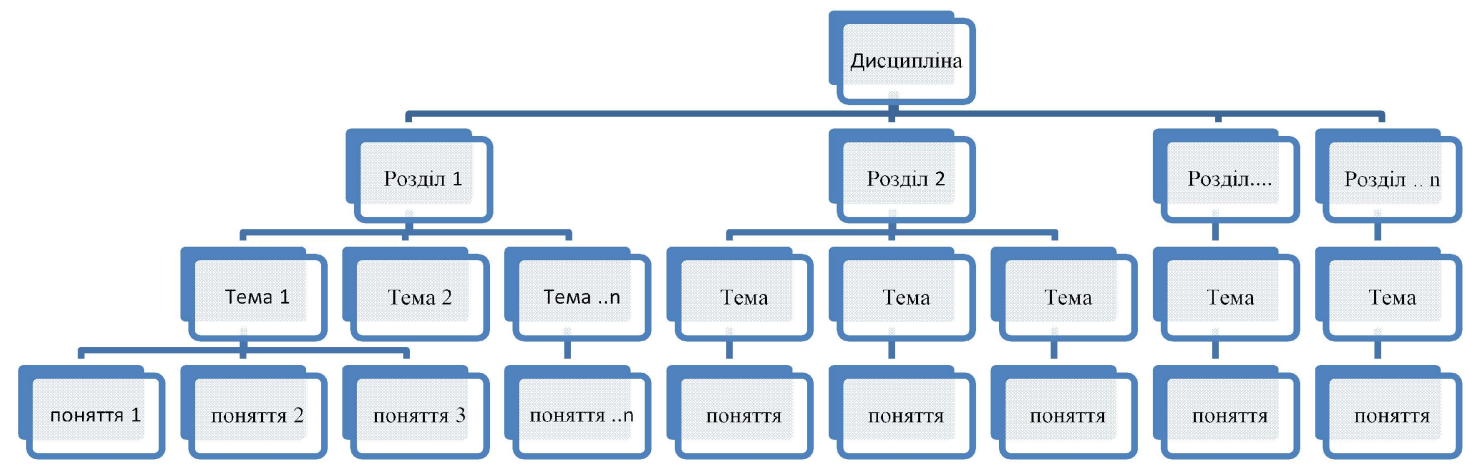

Рис. 1. Схематичне зображення системи "Дисципліна, розділ, тема, поняття"

Фундаменталізація понять передбачає виділення саме тих понять, які будуть базовими, фундаментальними для студентів технічних спеціальностей. Аналогічно відбувається фундаменталізація тем дисципліни вища математика. Дослідження щодо виділенню фундаментальних розділів “вищої математика”у застосуванні галузі 17-Електроніка та телекомунікації описано у нашій роботі [1].

Наведемо приклад фундаменталізації поняття “границя функції”, що належить до виділеного експертами фундаментального розділу вищої математики. Вивчення цього поняття та його фундаменталізація відбувається поетапно.

Перший етап - теоретичний. На ньому студенти технічних спеціальностей засвоюють базові теоретичні відомості про поняття границі, властивості границь послідовностей та функцій, методи обчислення.

Другий етап - практичний. За допомогою системи дій у студентів технічних спеціальностей формуються навички до обчислення границь послідовностей та функцій, вміння підбирати методи обчислення границь до різного типу функцій, розкривати невизначеності різного типу. На цьому етапі пропонується класифікувати відомі методи обчислення границь, шляхи розкриття основних невизначеностей. Для прикладу можна використати запропоновану класифікацію та розкриття основних невизначеностей [7].

Третій етап - діяльнісно-застосовний. Цей етап, на відміну від двох попередніх більш розтягнутий у часі, передбачає систематичне повторення поняття, застосування його у прикладних задачах а також систематичне повторення його властивостей при подальшому вивченні тем вищої математики (дослідження рядів на збіжність, дослідження на збіжність невласних інтегралів тощо).
На третьому етапі фундаменталізації понять відбувається орієнтація на відповідну технічну спеціальність, за якою навчаються студенти. На цьому етапі розв'язання можна запропоновувати студентам завдання.

Динамічна самоіндукція антени при постійному подовженні хвилі на одиницю довжини виражається формулою $L=L_{0} \frac{\operatorname{tg}(\pi l / \lambda)}{2 \pi l / \lambda}-$ де, $L$ - динамічна самоіндукція; $L_{0}$ - статична самоіндукція; $l$ - діюча довжина антени; $\lambda$ довжина хвилі антени. Знайти $\lim _{\lambda \rightarrow \infty} L$

Переформулюйте умову завдання математичною мовою. Знайдіть границю послідовності $\lim _{\lambda \rightarrow \infty} L_{0} \frac{\operatorname{tg}(\pi \cdot l / \lambda)}{2 \cdot \pi \cdot l / \lambda}$.

Результатом фундаменталізації освітнього процесу у технічному закладі вищої освіти $є$ низка особливих характеристик, що сформувалися у майбутнього фахівця-інженера, зокрема це:

- узгодженість теоретичних та практичних знань 3 розумінням важливості матеріалу, що вивчається;

- націленість майбутнього фахівця на виділення головного із загальної структури навчального матеріалу (виділення ядра інваріантних знань) 3 метою інтегрування його в подальших професійних дослідженнях;

- високий рівень вмотивованості студентів, що обгрунтоване їхнім розумінням цінності, застосовності програмного матеріалу;

- сформованість сприймати навчальний матеріал 3 різних дисциплін цілісно, розуміючи міждисциплінарні взаємозв'язки.

\section{Висновки.}

1. На сьогоднішній день серед науковців немає єдиного підходу щодо тлумачення дефініції 


\section{ПОБУДОВАПЕДАГОГІЧНОЇ СИСТЕМИ ФУНДАМЕНТАЛІЗАЦЇ МАТЕМАТИЧНОӤ ПІГГОТОВКИ МАЙБУТНІХБАКАЛАВРІВ ТЕХНІЧНИХСПЕЦАЛЬНОСТЕЙ}

“фундаменталізація”. Логіко-інтуїтивні визначення цього поняття дають можливість так сформувати його в загальних рисах: фундаменталізація математичної підготовки майбутніх бакалаврів технічних спеціальностей - це педагогічна система, впровадження якої у освітній процес зумовлює істотне підвищення рівня математичної підготовки студентів.

2. Під педагогічною системою розуміємо комплекс взаємопов'язаних структурних елементів, які у поєднанні дають змогу створити умови для досягнення педагогічних цілей освітнього процесу. Педагогічну систему фундаменталізації математичної підготовки складають гностичний, організаторський, конструктивний, комунікативний, проектувальний складові.

3. Фундаменталізація математичних понять $\epsilon$ частиною фундаменталізації математичної підготовки майбутніх бакалаврів відповідно до їхньої спеціальності.

4. Результатом фундаменталізації математичної підготовки майбутніх бакалаврів технічних спеціальностей $є$ низка особливих характеристик (інваріантних знань, вмінь, сформованість мотивів навчання), що сформувалися у майбутнього фахівця-інженера.

Перспективи подальших досліджень. Подальші дослідження фундаменталізації математичної підготовки майбутніх бакалаврів технічних спеціальностей ми вбачаємо у описі експериментального дослідження ефективності побудованої педагогічної системи.

\section{ЛІТЕРАТУРА}

1. Барась С. Т., Коломієць А.А. Зміст фундаментальної математичної підготовки студентів радіотехнічних спеціальностей. Вісник Вінницького політехнічного інституту. 2016. № 6. С.115-120.

2. Беспалько В. П. Образование и обучение с участием компьютеров (педагогика третьего тысячелетия). Москва, 2002. 352 с.

3. Жижко Т. А. (2005) Педагогічна система один із чинників впровадження ідеї інтенсифікації у професійній підготовці майбутніх фахівців. Науковий часопис НПУ імені М.П. Драгоманова. Серія 11 : Соціологія. Соціальна робота. Соціальна педагогіка.Управління: зб. наукових працьь. Київ, 2005. Вип. 3. С. 144-151.

4. Ісаєва О., Беата Кушка. Фундаменталізація як важлива складова вищої технічної освіти. Молодь і ринок, №4(190), 2021.

5. Клочко В.І., Коломієць А. А. Професійно спрямована фундаменталізація навчання математики. Наукові записки Вінницьького державного пед. ун.-ту ім. М.Коиюбинського. Серія: Педагогіка і психологія: зб. наук. пр. 2014. Вип. 41, С.184-187.

6. Ковтонюк М.М. Фундаменталізація професійної підготовки майбутнього вчителя математики бакалавра : монографія. Вінниця, 2013. 425 с.

7. Коломієць А. А., Клочко В.І., Краєвський В.О. Практикум 3 вищої математики: обчислення границь : практикум. Вінниця, 2020. 56 с.

8. Коломієць А.А. Реалізація системотвірної функції фундаменталізації математичної підготовки фахівців технічних спеціальностей. Педагогіка безпеки : Міжнародний науковий журнал. 2017. №1(2), С. 65-70.

9. Кузьмина Н.В. Понятие "педагогической системы” и критерии ее оценки. Методы систематичного педагогического исследования. 2-е изд. Народное образование, 2002. С. 7-52.

10.Педагогика: Учебное пособие для студентов педагогических учебных заведений. Ред. В.А. Сластенин и др. 4-е изд. Москва, 2004. 512.

11. Семеріков С. О. Фундаменталізація навчання інформативних дисциплін у вищій школі : монографія. Наук. ред. М. І. Жалдак. Київ, 2009. $340 \mathrm{c}$.

12. Философский словар. Ред. И. Т. Фролова. 5-е изд. Москва. Политиздат.1987. 590 с.

13. Чернілевський Д.В. та ін. Методологія наукової діяльності: навч. посібн. : вид. 2-ге, допов. Вінниця, 2010. С.171-172.

\section{REFERENCES}

1. Baras, S. T. \& Kolomiiets, A. A. (2016). Zmist fundamentalnoyi matematychnoyi pidhotovky studentiv radiotekhnichnykh spetsialnostey [Content of fundamental mathematical training of students of radio engineering specialties]. Bulletin of Vinnytsya Polytechnic Institute. No. 6. pp. 115-120. [in Ukrainian].

2. Bespalko, V.P. (2002). Obrazovaniye i obucheniye s uchastiyem kompyuterov (pedagogika tretyego tysyacheletiya) [Education and training with the participation of computers (pedagogy of the third millennium)]. Moscov, 352 p. [in Russian].

3. Zhyzhko, T. A. (2005). Pedahohichna systema odyn iz chynnykiv vprovadzhennya ideyi intensyfikatsiyi u profesiyniy pidhotovtsi maybutnikh fakhivtsiv [Pedagogical system is one of the factors implementing the idea of intensification in the professional training of future professionals]. Scientific journal of NPU named after Mykhaylo Drahomanov. Series 11: Sociology. Social work. Social pedagogy. Management: Coll. scientific works. Kyiv, Vol. 3. pp. 144-151. [in Ukrainian]. 
4. Isayeva, O. \& Beata Kushka (2021). Fundamentalizatsiya yak vazhlyva skladova vyshchoyi tekhnichnoyi osvity [Fundamentalization as an important component of higher technical education]. Youth \& market. Vol. 4(190), pp.35-39. [in Ukrainian].

5. Klochko, V.I. \& Kolomiiets, A.A. (2014). Profesiyno spryamovana fundamentalizatsiya navchannya matematyky [Professionally oriented fundamentalization of mathematics teaching]. Scientific notes of Vinnytsia State Pedagogical University. University named after M. Kotsyubynskiy. Series: Pedagogy and Psychology: Coll. Science. works. Vol. 41, pp. 184-187. [in Ukrainian].

6. Kovtonyuk, M. M. (2013). Fundamentalizatsiya profesiynoyi pidhotovky maybutnoho vchytelya matematyky - bakalavriv [Fundamentalization of professional training of the future teacher of mathematics]. 425 p. [in Ukrainian].

7. Kolomiiets, A.A., Klochko, V.I. \& Krayevskyy, V.O. (2020). Praktykum z vyshchoyi matematyky: obchyslennya hranyts [Workshop on higher mathematics: calculation of boundaries: workshop]. Vinnytsya, 56 p. [in Ukrainian].

8. Kolomiiets, A.A. (2017). Realizatsiya systemotvirnoyi funktsiyi fundamentalizatsiyi matematychnoyi pidhotovky fakhivtsiv tekhnichnykh spetsialnostey [Implementation of the system-forming function of fundamentalization of mathematical training of technical specialties]. Security Pedagogy: International Scientific Journal. No.1(2), pp. 6570. [in Ukrainian].

9. Kuzmina, N.V. (Ed.). (2002). Ponyatiye "pedagogicheskoy sistemy" I kriterii yeye otsenki [The concept of "pedagogical system" and the criteria for its assessment]. Methods for systematic pedagogical research. 2nd ed. Public education. Moscov, pp. 7-52. [in Russian].

10. Slastenin, V.A., Isayev, I.F., Mishchenko, A.I. \& Shiyanov, Ye.N. (2004). Pedagogika: uchebnoye posobiye dlya studentov pedagogicheskikh uchebnykh zavedeniy [Pedagogy: textbook for students of pedagogical educational institutions]. 4th ed. Moscov. 512 p. [in Russian].

11. Semerikov, S. O. (2009). Fundamentalizatsiya navchannya informatyvnykh dystsyplin u vyshchiy shkoli [Fundamentalization of teaching informative disciplines in high school]. (Ed.). M. I. Zhaldak. Kyiv, 340 p. [in Ukrainian].

12. Filosofskiy slovar (1987). [Philosophical Dictionary]. (Ed.) I. T. Frolova. $5^{\text {th }}$ ed. Moscow, 590 p. [in Russian].

13. Chernilevskyy, D.V. (Ed). (et al). (2010). Metodolohiya naukovoyi diyalnosti [Methodology of scientific activity]. Textbook. Vol. 2nd edition, supplemented. Vinnytsya, pp.171-172.

\title{
G508

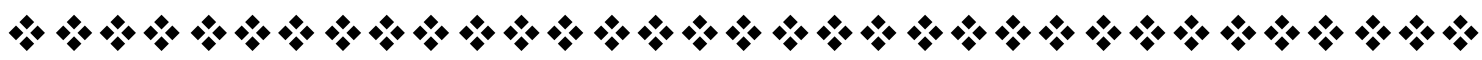

"Якщо Ви по-справжньому вірите в те, що робите, не дозволяйте ніяким обставинам стримувати Вас. Кращі в світі досягнення стали можливими не “ЗАВDЯКИ", а “ВСУТЕРЕЧ". Толовне - робити свою справу”.

\author{
Dейл Карнегі \\ американський педагог
}

“Роқами нақопичений досвід може посперечатися із знанням”.

Рассел Аінқольн Акобб америқанський вчений

“Будь-яқе навчання людини - ие не що інше, якмистецтво сприяти прагненню природи до свого розвитку".

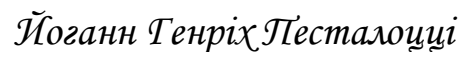
видатний швейцарський педагог-новатор

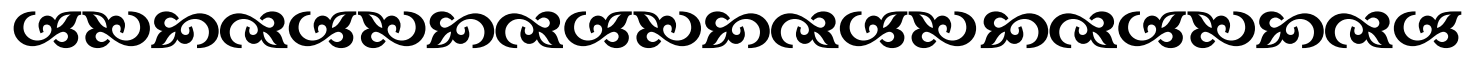

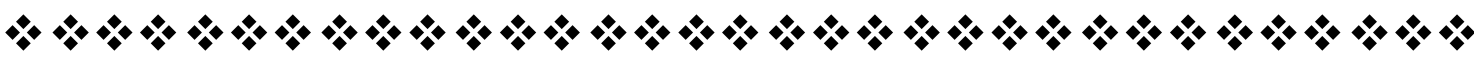

